\title{
PENGARUH KUALITAS PENDIDIKAN DAN PROMOSI TERHADAP PEROLEHAN JUMLAH SISWA PADA SEKOLAH MENENGAH ATAS SWASTA MAARIF KOTA CILEGON BANTEN
}

\author{
Ahmad Sofan Ansor \\ Dosen Politeknik PGRI Banten \\ e-mail:sopanansor65@gmail.com
}

Received: 19-07-2018, Accepted: 25-07-2018, Published:30-07-2018

\begin{abstract}
In the era of global competition, especially in the field of very strict education and vying to get the maximum number of students, it makes secondary school management spur any education providers trying to improve the quality of education in schools in order to compete with other schools. Based on these interests, it is necessary to conduct a research to hold improvement efforts in increasing the number of students, so it can be seen whether there is influence between the quality of education and promotion of secondary schools to the acquisition of the number of students in Maarif Cilegon High School (SMA). The result of the research shows that the quality of education and promotion of secondary schools has influenced the number of high school students achievement Maarif Cilegon, it is proved from the analysis result obtained that the value of Fhitung $(238,446)$. Ftable $(3.673)$ with degrees of freedom (df) 2 and 113 on alpha ( $\alpha$ ) 0.05, so the hypothesis that take is Ho rejected and $\mathrm{H} 1$ accepted. The quality of education has a significant influence on the Total Achievement of Maarif Cilegon High School students: tcount $(7,750)>$ ttable $(1,9818)$ with free degrees (df) 113 on alfa (a) 0.025 , so his decision reject Ho and accept H1. The promotion of SMA Maarif also has a significant influence on the acquisition of the number of students of Maarif Ccilegon High School which is: tcount $(15,290)>$ ttable $(1,9818)$ with free degree (df) 113 on alfa $(\alpha) 0,025$, so his decision reject Ho. and receive $H 1$. Coefficient of Determination $\left(R^{2}\right)$ of $80.8 \%$, which means that the diversity of High School Students (Maarif Cilegon) High School Achievement is due to the diversity of Education Quality and Promotion of Maarif High School, while the remaining $19.2 \%$ is due to other factors in research this is not analyzed further.
\end{abstract}

Keywords: quality of education, promotion, acquisition of number of students.

\begin{abstract}
Dalam era persaingan global khususnya dibidang pendidikan yang sangat ketat dan berlomba-lomba untuk mendapatkan jumlah siswa sebanyak-banyaknya, maka menjadikan manajemen sekolah menengah memacu setiap penyelenggara pendidikan berusaha meningkatkan kualitas pendidikan di sekolah agar dapat bersaing dengan sekolah lain. Berdasar kepentingan tersebut, perlu dilakukan suatu penelitian untuk diadakan usahausaha perbaikan dalam meningkatkan perolehan jumlah siswa, sehingga dapat diketahui apakah terdapat pengaruh antara kualitas pendidikan dan promosi sekolah menengah terhadap perolehan jumlah siswa di Sekolah Menengah Atas (SMA) Maarif Cilegon. Dari hasil penelitian menunjukkan bahwa kualitas pendidikan dan promosi sekolah menengah secara bersama-sama telah mempengaruhi Jumlah perolehan siswa SMA Maarif Cilegon, hal ini dibuktikan dari hasil analisa didapat bahwa nilai $F_{\text {hitung }}(238,446)>F_{\text {table }}(3,673)$
\end{abstract}


dengan derajat bebas (df) 2 dan 113 pada alfa (a) 0,05, sehingga hipotesis yang ambil adalah $\mathrm{Ho}$ ditolak dan $\mathrm{H}_{1}$ diterima. Kualitas pendidikan mempunyai pengaruh yang signifikan terhadap Jumlah Perolehan Siswa SMA Maarif Cilegon yaitu : nilai $t_{\text {hitung }}(7,750)>t_{\text {table }}$ $(1,9818)$ dengan derajat bebas (df) 113 pada alfa $(\alpha)$ 0,025, sehingga keputusannya menolak Ho dan menerima $\mathrm{H}_{1}$. Promosi SMA Maarif juga mempunyai pengaruh yang signifikan terhadap Perolehan Jumlah Siswa SMA Maarif Ccilegon yaitu : nilai thitung $(15,290)$ $>t_{\text {table }}(1,9818)$ dengan derajat bebas (df) 113 pada alfa (a) 0,025, sehingga keputusannya menolak Ho. dan menerima $\mathrm{H}_{1}$. Koefisien Determinasi $\left(\mathrm{R}^{2}\right)$ sebesar $80,8 \%$, yang berarti bahwa keragaman Perolehan Jumlah Siswa Sekolah menengah (SMA) Maarif Cilegon disebabkan oleh keragaman Kualitas Pendidikan dan Promosi sekolah menengah Maarif, sedangkan sisanya 19,2\% keragamannya disebabkan oleh faktor lain yang dalam penelitian ini tidak dianalisis lebih lanjut.

Kata Kunci : Kualitas pendidikan, promosi, perolehan jumlah siwa.

\section{PENDAHULUAN}

Persaingan penyedia program pendidikan saat ini, perlu adanya informasi yang cepat, kualitas layanan tiap program studi yang sesuai kebutuhan pasar dan promosi yang tepat serta adanya metode analisis yang akurat. Terlebih lagi pada kondisi kebutuhan pasar yang terpilah-pilah, dimana pasar massal telah terpecah dan berubah menjadi pasar kecil yang menuntut berbagai spesialisasi model, warna, jenis produk, ukuran, kualitas dan sebagainya. Untuk itu sangat diperlukan pemahaman yang sangat kongkret dan rinci mengenai kondisi pasar, perilaku masyarakat sebagai konsumen maupun kebiasaankebiasaan umum lainnya. Persaingan dibidang pendidikan saat ini sangat ketat dan berlomba-lomba untuk memperoleh dan mendapatkan jumlah siswa sebanyak-banyaknya, sehingga menjadikan manajemen Sekolah Menengah Atas (SMA) memacu setiap penyelenggara pendidikan berusaha meningkatkan kualitasnya agar dapat bersaing memasuki pasar bebas dan arus informasi global. Promosi adalah salah satu cara yang efektif untuk merekrut dan menarik siswa sebanyak-banyaknya, hal ini dikarenakan pembiayaan operasional perguruan pendidikan swasta sangat tergantung pada jumlah siswa yang diperoleh.

Kualitas pendidikan harus dioptimalkan, sehingga dalam sebuah pernyataan para ahli bahwa perusahaan yang selalu memuaskan kebutuhan konsumennya disebut perusahaan berkualitas. Kesesuaian dan kualitas kinerja persyaratan merupakan kebutuhan pelanggan, dengan kata lain keseluruhan karakteristik produk dan jasa yang 
dapat memuaskan kebutuhan konsumen atau sesuai persyaratan yang dikehendaki konsumen, bukan persyaratan perusahaan. Kualitas merupakan salah satu faktor utama keunggulan kompetitif tujuan organisasi yang mempunyai manajemen yang sudah mapan. Tujuan setiap organisasi yang manajemennya sudah baik adalah untuk menghasilkan barang dan jasa yang berkualitas baik dan dapat memuaskan konsumen sesuai kebutuhannya. Promosi yang agresif, positif dan memenuhi segmen pasar akan dapat secara efektif memenuhi target jumlah penerimaan siswa. Promosi yang dilakukan melalui media cetak, surat kabar, media elektronik, penyebaran brosur, pemasangan spanduk dan personal aproach sesama siswa dan para guru adalah sangat membantu dalam memperoleh jumlah siswa.

Mengukur kualitas jasa pendidikan lebih sukar dari pada mengukur kualitas produk atau barang manufaktur. Kualitas produk manufaktur yang diproduksi melalui proses produksi yang terkontrol dalam suatu pabrik kemudian diserahkan pada konsumen, sedang kualitas jasa pendidikan diberikan atau dirasakan selama proses interaksi antara siswa dan penyelenggara pendidikan serta output produk pendidikan. Untuk mendapatkan kualitas yang tinggi setiap organisasi harus melakukan identifikasi kebutuhan dan keinginan pemakai, mengkomunikasikan harapan pelanggan kepada perancang produk, memastikan pesanan pelanggan secara benar dan tepat waktu, memastikan pelanggan telah mendapat instruksi, pelatihan, dan bantuan teknis pemakaian produk, harus tetap berhubungan setelah penjualan untuk memastikan pelanggan produk puas, juga mengumpulkan gagasan pelanggan untuk kesempurnaan produk yang dalam hal ini produk pendidikan.

Kualitas pendidikan menengah atas berdasar penetapan akreditasi yang ditentukan oleh Badan Akreditasi Sekolah Nasional (BASNAS) dengan menilai kualitas berdasar peringkat. Untuk itu pendidikan di Sekolah Menengah Atas (SMA) Maarif Cilegon harus memenuhi tuntutan akreditasi berdasar kebutuhan masyarakat setiap program studinya memiliki jaminan kualitas (quality assurance), pengendalian kualitas (quality contro) dan perbaikan qualitas (quality improvement). Pendidikan menengah 
(SMA) tidak sebatas memiliki kemampuan untuk menghasilkan lulusan yang diukur secara akademik, melainkan keseluruhan program lulusannya harus mampu membuktikan prestasi dan dapat diterima diberbagai bidang pekerjaan yang sesuai dengan bidang ilmunya. Evaluasi produk pendidikan menengah ditentukan oleh pengakuan masyarakat pengguna lulusan SMA.

Competitive Strategi harus diciptakan agar posisi pendidikan menengah memiliki posisi tawar yang kuat (bargaining power) dalam persaingan mendapatkan pengakuan masyarakat. Tujuan dan fungsi manajemen secara kolektif harus memiliki posisi yang kuat di pasar dan tumbuh berdasarkan kekuatan perguruan menengah, serta diperbaharui terus sesuai perubahan peluang dan ancaman eksternal. Perguruan Menengah juga harus memiliki kompetensi khusus (distintive competency) sebagai pendorong (drivers) untuk menjalankan proses pembelajaran seperti reputasi perguruan menengah dan biaya yang terjangkau.

Sekolah Menengah Atas (SMA) Maarif saat ini mempunyai siswa sebanyak 153 orang siswa dengan enam (6) rombongan belajar kelas yang dibagi menjadi dua (2) ruang kelas I, dua (2) ruang kelas II dan dua (2) ruang kelas III, sehingga jika dihitung dari perbandingan kapasitas ruangan dengan jumlah siswa adalah : 153 orang siswa dibagi 6 ruangan = 25,5 atau 26 orang siswa per ruangan, sedang kapasitas per ruangan adalah 35 sampai 40 orang siswa, sehingga daya tampung ruangan sekolah SMA Maarif Cilegon dapat dikategorikan masih kurang siswa. Akreditasi sekolah hasil pengukuran Badan Akreditasi Sekolah didapatkan akreditasi "C". Melihat potensi sekolah yang berada dalam dukungan Yayasan Pendidikan Maarif Cilegon, tanah yang cukup luas, kategori guru pengajar yang sudah bersertifikasi dan dukungan alumni, maka kemajuan sekolah akan lebih baik. Kasus ini menarik untuk diteliti agar diketahui faktor penentu kemajuan sekolah dalam meningkatkan jumlah penerimaan siswa.

Mencermati permasalahan dan kenyataan yang ada, bahwa pihak sekolah perlu meningkatkan kualitas pendidikan dan promosi sekolah agar tercapai peningkatan perolehan jumlah siswa. Untuk itu penelitian diatas difokuskan pada Pengaruh Kualitas 
Pendidikan dan Promosi Sekolah terhadap Perolehan Jumlah Siswa pada Sekolah Menengah Atas (SMA) Maarif Kota Cilegon, Banten.

\section{Perumusan Masalah}

Berdasar permasalahan hal tersebut diatas maka permasalahan yang penelitian ini dapat dirumuskan sebagai berikut:

(1) Apakah kualitas pendidikan berpengaruh langsung terhadap perolehan jumlah siswa?

(2) Apakah promosi sekolah berpengaruh langsung terhadap perolehan jumlah siswa?

(3) Apakah kualitas pendidikan dan promosi secara bersama-sama memiliki hubungan dengan perolehan jumlah siswa.

\section{Tujuan Penelitian}

Tujuan penelitian yang ingin dicapai dalam penelitian ini adalah untuk memperoleh gambaran yang nyata serta menganalisa tentang pengaruh kualitas pendidikan dan promosi terhadap perolehan siswa. Adapun penelitian ini bertujuan untuk mengetahui: (a) Apakah terdapat pengaruh langsung kualitas pendidikan terhadap perolehan siswa. (b) Apakah terdapat pengaruh langsung promosi sekolah terhadap perolehan siswa. (c) Apakah kualitas pendidikan dan promosi secara bersama-sama memiliki hubungan dengan perolehan jumlah siswa. (d) Memprediksi besarnya konstribusi pada masing-masing variabel: kualitas pendidikan, promosi dan perolehan jumlah siswa. (e) Memperkaya ilmu pengetahuan khususnya manajemen pemasaran pendidikan.

\section{TINJAUAN TEORITIS}

\section{Hakekat Kualitas Pendidikan}

Difinisi relatif tentang mutu menurut Edward Salis (2008:53-56) memiliki dua aspek, (1) menyesuaikan dengan spesifikasi, (2) memenuhi kebutuhan pelanggan. Cara pertama sering disimpulkan dengan "sesuai dengan tujuan dan manfaat". Mutu diperoleh melalui produk dan layanan yang memenuhi spesifikasi awal yang telah ditetapkan dalam gaya yang konsisten. Mutu memiliki sebuah system yang biasa disebut dengan system jaminan mutu (quality assurance system). Sebuah produk dikatakan bermutu bila secara konsisten sesuai tuntutan pembuatnya. Cara kedua mutu sesuai persepsi (quality in perception). Mutu ini bisa disebut sebagai mutu yang 
hanya ada dimata orang yang melihatnya, para pelanggan adalah pihak yang membuat keputusan tentang mutu. Standar pelanggan meliputi kepuasan pelanggan, memenuhi kebutuhan pelanggan dan menyenangkan pelanggan.

Kualitas atau mutu memiliki definisi dari yang tradisional sampai dengan strategis dimana aspek tradisional, kualitas menggambarkan karakteristik langsung dari suatu aspek produk seperti: kinerja (performance), keadaan (reliability), mudah dalam penggunaan (easy to use), estetika (estetics), dan sebagainya. Sedangkan pengertian kualitas dari aspek strategis adalah segala sesuatu yang mampu memenuhi keinginan atau kebutuhan pelanggan (meeting the needs of customers). Kualitas kerja yang baik berarti kualitas sumber daya manusia mempunyai karakteristik yang baik pula, sehingga mampu memenuhi keinginan atau kebutuhan pelanggan, yaitu pihak-pihak yang berkepentingan dengan kerja aparatur. (Kottler, 1997) Kualitas diartikan sebagai totalitas karakteristik suatu produk yang dapat memuaskan kebutuhan konsumen secara fisik. Kualitas seringkali diartikan sebagai kepuasan atau kesesuaian dengan persyaratan yang dibutuhkan pelanggan. Di samping pengertian di atas, kualitas juga dapat diartikan sebagai segala sesuatu yang menentukan kepuasan pelanggan dan upaya perubahan ke arah perbaikan terus-menerus sehingga dikenal istilah: Q-MATCH (Quality = Meets Agreed Terms and Changes). Ini berarti bahwa kualitas kerja aparatur yang baik mengacu kepada persyaratan teknis, kebutuhan pihak terkait dan perubahan terus-menerus sesuai perubahan. (Soekarsono, R., 2003)

Kualitas atau Mutu merupakan kata kunci dalam dunia usaha dan perindustrian untuk dapat bersaing. Peningkatan produksi secara terusmenerus ini juga harus dilakukan dengan peningkatan kualitas, baik kualitas dalam pelayanan terhadap konsumen, kualitas/mutu produk yang diproduksi maupun kualitas pengiriman (delivery quality). Tidak hanya sampai tercapainya pemenuhan standar spesifikasi. Pola pikir seperti ini adalah asumsi kualitas statis, yang dapat menghambat segala perbaikan dan inovasi lebih lanjut. Permasalahan kualitas selalu ditentukan oleh semua pihak, karena efek yang paling berarti dari peningkatan kualitas adalah terjadinya peningkatan produktivitas, peningkatan mutu pelayanan dan 
mutu/kualitas produk yang dikirim (shipment). Salah satu pihak yang ikut berperan besar dalam penentuan masalah kualitas adalah pelanggan (customer). Kesuksesan suatu perusahaan dinilai dari kepuasan pelanggan (customer satisfaction). Tantangan suatu perusahaan bukanlah untuk sekedar memuaskan para pelanggan, tetapi juga untuk menjadikan mereka lebih puas lagi dari yang sebelumnya dan produk barang atau jasa tersebut harus lebih baik dari perusahaan sejenis yang lain (Saragih, 2004).

Menurut The American Society for Quality Control kualitas didasarkan kepada pemenuhan kepuasan pelanggan, "The Totality of features and characteristics of a product or service that bear on its ability to satisfy stated or implied needs" (Heizer, 1996). Peningkatan keuntungan (Increased Profit) didapatkan dengan melakukan perbaikan kualitas (Improved Quality). Perbaikan kualitas ditujukan untuk penetrasi pemasaran (market gains) dan mengurangi biaya produksi (reduced costs). Kualitas product sangat menentukan biaya dan pasar penjualan (cost and market share), reputasi perusahaan (company's reputation), keunggulan product (product liability) dan pengaruh internasional (international implications). Standart kualitas internasional biasa dikenal dengan Japan's Industrial Standart (JIS), Europe's ISO 9000 Standart and American Standart (Heizer, 1996).

Kualitas Jasa ditentukan oleh lima dasar yaitu keandalan (reliabity), daya tanggap (responsiveness), Jaminan kepastian (assurance), Sikap peduli (emphaty) dan bukti fisik (tangibles). Kualitas suatu product tergantung kesesuain pada pemenuhan kepuasan pemakai, fitness for use. Beberapa alat untuk digunakan dalam memecahkan masalah dipakai statistical process control (SPC). Quality trilogy menurut Juran (Schonberger, 1997) meliputi (a) Quality Planning, dimana perencanaan kualitas merupakan proses untuk merencanakan kualitas sesuai dengan tujuan. Dalam proses ini pelanggan diidentikan dan produk yang sesuai dengan kebutuhan dikembangkan. (b) Quality Control dimana kontrol kualitas merupakan proses mencapai tujuan selama operasi. Kontrol kualitas melalui lima tahap yaitu menentukan apa yang seharusnya di kontrol, menentukan unit-unit pengukuran, menetapkan standar kerja, mengukur 
kinerja dan mengevaluasi dengan membandingkan antara kinerja sebenarnya dengan standar kinerja. (c) Quality Improvement dimana perbaikan kualitas untuk mencapai kinerja yang lebih tinggi.

Akreditasi adalah penentuan standar mutu serta penilaiannya terhadap suatu lembaga pendidikan (dalam hal ini sekolah menengah oleh pihak diluar lembaga pendidikan itu sendiri. Kriteria sekolah menengah menurut Barnet (1992) dalam BASN sekolah menengah (2002) adalah : Sekolah menengah sebagai penghasil tenaga kerja yang bermutu (quality man power). Siswa merupakan output sekolah menengah yang memiliki nilai dalam pasaran tenaga kerja dan keberhasiannya diukur berdasarkan tingkat penyerapan tenaga kerja lulusan tersebut dalam masyarakat. Sekolah menengah sebagai lembaga pelatihan bagi karier peneliti. Mutu sekolah menengah ditentukan oleh penampilan, prestasi peneliti, anggota staf. Sekolah menengah sebagai organisasi pengelola pendidikan yang efisien. Sekolah menengah dianggap baik bila dengan sumber daya alam dan dana yang tersedia, jumlah siswa yang lewat proses pendidikannya semakin besar. Sekolah menengah sebagai indikator sukses terletak pada cepatnya upaya memperluas dan mempertinggi jumlah siswa dan variasi jenis program dan fasilitas yang ditawarkan.

\section{Hakekat Promosi Sekolah}

Promosi sekolah yaitu usaha memperkenalkan sekolah dalam rangka memasarkan sekolah. Usaha Pemasaran adalah suatu proses sosial dan manajerial yang didalamnya individu dan kelompok mendapatkan apa yang mereka butuhkan dan inginkan dengan menciptakan, menawarkan dan mempertukarkan produk yang bernilai dengan pihak lain. Berdasar definisi tsb konsep pemasaran bersandar pada kebutuhan (needs), keinginan (wants), permintaan (demands), produk (barang, jasa dan gagasan), nilai, biaya, kepuasan, pertukaran, dan transaksi, hubungan, dan jaringan, pasar, serta pemasar dan prospek. Kunci konsep pemasaran dalam mencapai tujuan organisasi adalah menjadi lebih efektif daripada para pesaing dalam memadukan kegiatan pemasaran guna menetapkan dan memuaskan kebutuhan dan keinginan pasar sasaran. Empat pilar konsep pemasaran yaitu pasar sasaran, 
kebutuhan pelanggan, pemasaran terpadu dan profitabilitas.

Setiap alat promosi memiliki karakteristik dan biaya tersendiri, sekolah harus memiliki pemahaman terhadap karakteristik ini. Periklanan adalah satu cara promosi secara umum. Menurut Kotler $(1998,224)$ alat promosi meliputi, (1) periklanan, (2) promosi penjualan, (3) hubungan masyarakat dan publisitas, penjualan personal, (4) pemasaran langsung. Periklanan memiliki sifat umum, tersebar luas, ekspresi yang lebih kuat dan tidak bersifat pribadi. Iklan dapat melalui TV, media cetak, brosur, dan spanduk. Promosi penjualan memanfaatkan komunikasi, insentif dan ajakan. Daya tarik hubungan masyarakat dan publisitas didasarkan pada kredibilkitas yang tinggi, kemampuan menangkap pembeli yang tidak menduga, dan dramatisasi. Penjualan personal adalah alat yang paling efektif pada proses pembelian terutama dalam membangun preferensi, keyakinan, dan tindakan pembeli. Tiga manfaat penjualan personal yaitu adanya konfrontasi personal, mempererat dan memberikan tanggapan. Pemasaran langsung terdapat berbagai bentuk seperti melalui surat langsung, lewat telepon, dan pemasaran elektronik.

Konsep pemasaran bersandar pada kepuasan pelanggan, dimana kepuasan adalah perasaan senang seseorang yang berasal dari perbandingan antara kesannya dan kinerja atau hasil suatu produk dan harapan-harapannya. Pemasaran dibedakan berdasarkan kinerjanya yaitu pemasaran dasar, pemasaran reaktif, pemasaran bertanggung jawab, pemasaran proaktif dan pemasaran kemitraan. Pemasar proaktif selalu menghubungi pelanggan secara periodik dalam pemakaian produk dan menawarkan produk baru sedang pemasar kemitraan adalah bekerjasama dengan pelanggan untuk menemukan caracara penghematan dan membantu pelanggan berkinerja lebih baik. Kunci suskses usaha menurut Mc Kinsey adalah 7S yaitu Strategy, Structure, System, Style, Staff, Skill and Shared value. Sedang esensi pemasaran strategis yaitu rumusan pembagian, penentuan sasaran dan penentuan posisi atau biasa dikenal dengan Segmentation, Targeting and Positioning (STP). Bauran pemasaran adalah perangkat alat pemasaran yang digunakan untuk mencapai 
tujuan pemasaran. Menurut McCarty memperkenalkan 4P yaitu Product, Price, Place and Promotion. 4P merupakan pandangan penjual terhadap alat pemasaran untuk mempengaruhi pembeli. Robert Lauterbon menyarankan tanggapan terhadap 4P yaitu 4C, Costumer needs and wants, Cost to customer, Convenience (kemudahan memperoleh), and Communication.

\section{Hakekat Perolehan Jumlah Siswa}

Penjualan produk dalam memperoleh jumlah siswa adalah merupakan suatu hal yang harus dilakukan sebuah sekolah, sehingga sebuah sekolah akan tetap langgeng apabila dalam penjualan produk seperti perolehan jumlah siswa dapat meningkat. Penjualan menurut beberapa ahli adalah suatu produk dikatakan sukses bila produk tersebut dapat diproduksi dan laku dijual sehingga mendapatkan keuntungan. Ada beberapa strategi dalam penjualan antara lain: (1) strategic planning, (2) marketing planning, (3) production planning. (Freddy R., 2002). Sedangkan menurut Ulrich (2001) ada tiga fungsi yang selalu menyertai pengembangan produk yaitu; (1) pemasaran, perancangan, dan (3) sistem produksi.
Daya tarik suatu produksi ditentukan oleh faktor kreasi, kepuasan pemakai dan kebutuhan individu serta semangat anggota tim kreasi,. Sistem produksi pada sekolah menengah ditentukan oleh dosen, staf, peralatan, fasilitas, energi, buku-buku dan pengetahuan. Hasil produk sekolah menengah seperti siswa terdidik, riset dan pengabdian masyarakat. Sedangkan menurut Handoko, (2000). Akhir dari suatu perusahaan adalah mendapatkan keuntungan sebanyakbanyaknya.

Bedasarkan pendapat dari para ahli di atas, maka dapat di uraikan bahwa sekolah menengah dalam mendapatkan keuntungan dibutuhkan suatu masukan sebagai bahan baku produk yaitu jumlah siswa. Semakin banyak siswa yang partisipasi dalam belajar akan semakin banyak keuntungan yang didapat. Sekolah Menengah Atas (SMA) Maarif Cilegon agar tetap beroperasi, maka diperlukan adanya kontinuitas jumlah siswa sebagai pengguna jasa pendidikan. Untuk maksud inilah Sekolah Menengah Atas (SMA) Maarif Cilegon pada setiap penerimaan siswa baru selalu ikut peran aktif dalam rangka melakukan promosi untuk menerima calon-calon siswa baru, baik 
dari calon siswa sekitar sekolahan maupun calon siswa yang baru lulus dari SLTP luar daerah sekitar, sehingga dalam proses belajarmengajar ini akan tetap terselenggara. Saat ini SMA Maarfi Cilegon memiliki enam (6) ruang kelas yang ditempati oleh 153 orang siswa. Perolehan siswa setiap tahun sekitar 51 siswa, dan sekolah sudah berjalan selama 14 tahun.

\section{Kerangka Pemikiran.}

Hubungan antara kualitas pendidikan $\left(\mathrm{X}_{1}\right)$, promosi sekolah $\left(\mathrm{X}_{2}\right)$ terhadap peroleh jumlah siswa $(Y)$ sebagai berikut:

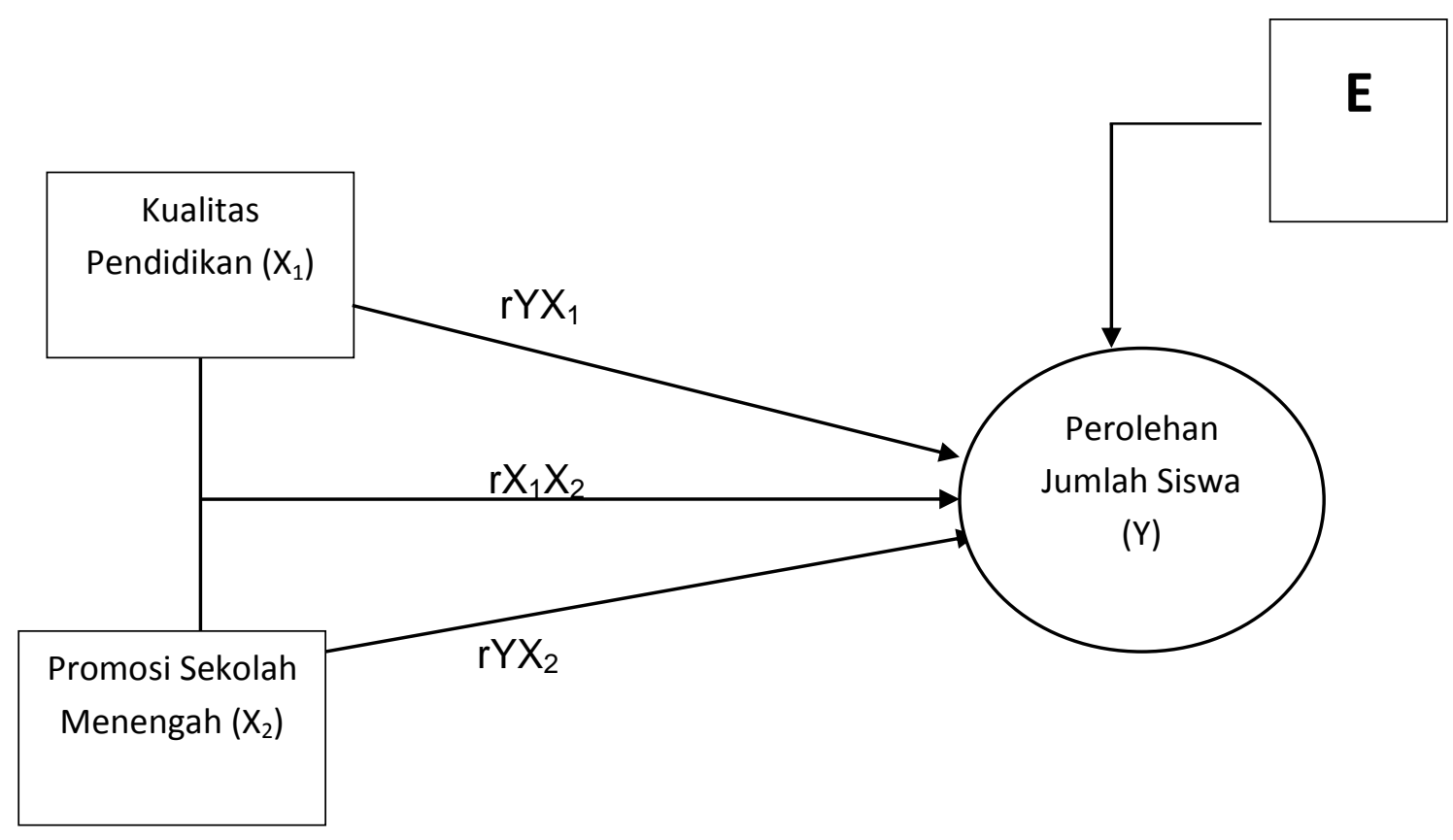

Keterangan Gambar :

$\mathrm{X}_{1}$ : Variabel Kualitas Pendidikan

$\mathrm{X}_{2}$ : Variabel Promosi Sekolah Menengah

Y : Variabel Perolehan Jumlah Siswa/Penjualan

$\boldsymbol{\varepsilon} \quad:$ Epsilon $=$ variabel-variabel lain yang mempengaruhi Perolehan jumlah siswa di luar $\mathrm{X}_{1}$ dan $\mathrm{X}_{2}$ yang tidak diteliti.

\section{Perumusan Hipotesis}

Berdasarkan kajian teoritis dan kerangka pemikiran di atas, bahwa hipotesis yang diajukan dalam 
penelitian ini dapat dirumuskan sebagai berikut:

1. Diduga terdapat hubungan positif antara kualitas pendidikan dengan perolehan siswa. Dengan kata lain bahwa semakin baik kualitas pendidikan, maka akan semakin meningkat perolehan jumlah siswa.

2. Diduga terdapat hubungan positif antara promosi sekolah menengah dengan perolehan jumlah siswa. Dengan kata lain bahwa semakin gencar dan informatif dalam promosi sekolah menangah, maka semakin meningkat perolehan jumlah siswa.

3. Diduga terdapat hubungan positif antara kualitas pendidikan dan promosi sekolah menengah secara bersama-sama terhadap perolehan jumlah siswa.

\section{METODE PENELITIAN}

Menggunakan teknik analisis statistik yang digunakan dinamakan analisis jalur (path analysis). Variabel yang dimaksud dalam penelitian ini adalah kualitas pendidikan $\left(\mathrm{X}_{1}\right)$, promosi sekolah $\left(\mathrm{X}_{2}\right)$ dan perolehan jumlah siswa (Y). Pengaruh antar variabel yang menggambarkan jalur (path) hubungan antara variabel $X_{1}$ dan $\mathrm{X}_{2}$ dengan $\mathrm{Y}$.

\section{Populasi dan Sampel}

Populasi target penelitian ini menggunakan purpose random sampling yaitu teknik pengambilan sampel dimana dari anggota populasi ditunjuk langsung dan ditentukan jumlahnya untuk dijadikan sampel penelitian dengan pengambilan secara acak proporsional Sugiono (2009:118). Dari populasi didapat 356 orang dengan menggunakan rumus sampel, $\mathrm{s}=\mathrm{N} / \mathrm{Nd}^{2}+1$, maka didapat sampel sebanyak 78 orang dan peneliti mengambil sampel sebanyak 116 orang.

\section{Jenis dan Sumber Data}

Jenis pengambilan data dalam penelitian ini adalah data primer yaitu data kuisioner isian data guru, siswa, staf administrasi sekolah, calon siswa dan orang tua murid disekitar 
sekolah. Sumber data yang digunakan adalah hasil tanggapan responden terhadap variabel yang diteliti yaitu kualitas pendidikan dan promosi.

\section{Metode Pengumpulan Data}

Metode pengumpulan data dalam penelitian ini menggunakan kuisioner yaitu pengumpulan data dengan memberikan daftar pertanyaan kepada responden di sekolah dan diluar sekolah dengan prosedur yaitu (1) membagikan kuisioner, (2) responden diminta mengisi kuisioner pada lembar jawaban yang disediakan, (3) lembar kuisioner dikumpulkan, diseleksi, diolah dan dianalisis.

\section{Pengujian validitas instrument}

Tujuan pengujian validitas butir instrument penelitian adalah untuk melihat keakurasian dan butir instrument dalam mengukur variabel yang dimaksud. Penentuan nilai kritis dilakukan dengan menggunakan distribusi $F$ dengan membandingkan antara nilai kritis $F_{\text {table }}$ dengan $F$ hitung $(F$ ratio) dari hasil perhitungan. Nilai $F$ hitung dapat diketahui dengan menggunakan program computer dengan melihat table Anova pada kolom $\mathrm{F}_{\text {ratio. }}$.

\section{Analisa Regresi Berganda}

\section{(Multiple Linear Regression)}

Model analisa statistik berdasarkan regresi berganda, digunakan untuk mengetahui pengaruh atau perkiraan terhadap nilai variabel terkait $(\mathrm{Y})$ dengan beberapa variabel bebas $\left(X_{1}, X_{2} \ldots \ldots, X_{n}\right)$, dan hubungan fungsional tersebut menggambarkan suatu rumusan fungsional $Y$ terhadap $X$, yang diformulasikan dalam bentuk persamaan berikut: $Y=f\left(X_{1}\right.$, $\mathrm{X}_{2} \ldots \ldots \ldots, \mathrm{X}_{\mathrm{n}}$ ). Adapun persamaan regresi berganda, secara umum khususnya dapat ditulis sebagai berikut:

$$
Y^{1}=a+b_{1} X_{1}+\ldots \ldots+b_{n} X_{n}
$$

Karena dalam penelitian ini hanya ada dua variabel independennya, maka persamaan regresi yang akan terbentuk sebagai berikut:

$$
Y^{1}=a=b_{1} X_{1}+b_{2} X_{2}
$$

Di mana:

$\mathrm{Y}^{1} \quad$ Nilai estimasi
variabel dependen


A

$=$ Titik potong kurya dengan sumbu $Y$

$\mathrm{X}_{1}=$ variabel independen 1

$\mathrm{X}_{2}=$ variabel independen dengan variabel $X_{1} X_{2}$

Untuk model regresi yang menggunakan dua variabel independen seperti kasus yang telah disebutkan di atas, persamaan regresi dari suatu data observasi dapat dibuat dengan menentukan besarnya a, $b_{1}$, dan $b_{2}$.

\section{Koefesien Determinan $\left(\mathbf{R}^{2}\right)$}

Koefesien determinan
digunakan untuk mengetahui
seberapa besar prosentasi
pengaruh dari variabel bebas
yaitu kualitas pendidikan dan
promosi sekolah secara
bersama-sama terhadap variabel
terikat yaitu perolehan jumlah
siswa dengan kata lain, jika $\mathrm{R}^{2}$
yang diperoleh dari hasil
perhitungan semakin besar
(mendekati 1) maka dikatakan
sumbangan dari variabel bebas
terhadap variabel terikat semakin
besar.

\section{HASIL PENELITIAN}

Untuk mengetahui benar tidaknya dugaan bahwa variabel bebas yang terdiri dari kualitas pendidikan (X1) dan promosi sekolah (X2) berpengaruh terhadap variabel perolehan jumlah siswa $(Y)$, maka dalam penelitian ini digunakan analisis kuantitatif dan alat uji statistika yang dipilih adalah regresi linier berganda dengan menggunakan alat bantu SPSS.

Besarnya nilai koefisien determinasi yang diperoleh dengan perhitungan SPSS tersebut sebesar 0,808 . hal ini menunjukkan bahwa 80,8\% keragaman variabel Perolehan Jumlah Siswa pada Sekolah menengah (SMA) Maarif Cilegon disebabkan oleh perbedaan keragaman variabel Kualitas Pendidikan dan variabel Promosi sekolah menengah, sisanya sebanyak $19,2 \%$ disebabkan oleh faktor lain yang pada penelitian ini tidak diteliti.

Hasil analisis data diperolah persamaan regresi sbb:

$\hat{Y}=a+b_{1} X_{1}+b_{2} X_{2}$

$\hat{Y}=28,347+0,190 X_{1}+0,328 X_{2}$ 
Persamaan regresi ini berarti bahwa:

1. Setiap kenaikan 1 (satu) skor variabel Kualitas Pendidikan dapat meningkatkan 0,190 skor variabel Perolehan Jumlah Siswa pada Sekolah menengah (SMA) Maarif Cilegon, dengan asumsi variabel Promosi sekolah menengah SMA Maarif tetap (Konstant).

2. Setiap kenaikan 1 (satu) skor variabel Promosi sekolah menengah dapat meningkatkan 0,328 skor variabel Perolehan Jumlah Siswa pada Sekolah menengah (SMA) Maarif Cilegon dengan asumsi variabel Kualitas Pendidikan Konstant.

Hasil Uji -t untuk menguji seberapa jauh pengaruh satu variabel independen secara individual dalam menerangkan variabel dependen.

\section{a. Uji Hipotesis Kualitas} pendidikan terhadap perolehan jumlah siswa.

Uji $\mathbf{t}$ untuk $\mathbf{b}_{1}$ dilakukan untuk menguji hipotesis kedua yaitu : Ho $: b_{1}=0$ tidak terdapat pengaruh Kualitas Pendidikan terhadap Perolehan Jumlah Siswa, $\mathrm{Hi}: \mathrm{b}_{1} \neq$
0 terdapat pengaruh Kualitas Pendidikan terhadap Perolehan Jumlah Siswa.

Jika $\mathrm{t}_{\text {hitung }}>\mathrm{t}$ tabel, maka $\mathrm{H}_{0}$ ditolak dan $\mathrm{H}_{1}$ diterima.

Hasil perhitungan uji t dengan bantuan pengolahan komputer berdasarkan perhitungan SPSS 15,0 diperoleh koefisien $t$ hitung untuk $b_{1}$ sebagai berikut:

$$
\begin{aligned}
& t_{\text {hitung }}=\frac{b_{1}}{\operatorname{Se}\left(b_{1}\right)} \\
& t_{\text {hitung }}=\frac{0,19002}{0,024518}=7,750
\end{aligned}
$$

Dari perhitungan SPSS tersebut nilai $t$ hitung yang diperoleh adalah sebesar 7,750 sedangkan $\mathrm{t}$ tabel (lampiran 4) dengan derajat bebas (df) 113 pada alfa (a) 0,025 adalah sebesar 1,9818. Dengan demikian $t$ hitung $(7,750)>t$ tabel $(1,9818)$, sehingga jelas $H_{0}$ ditolak dan $\mathrm{H}_{1}$ diterima. Hal ini menunjukkan bahwa Kualitas Pendidikan dapat meningkatkan Perolehan Jumlah Siswa pada Sekolah menengah (SMA) Maarif Cilegon 


\section{b. Uji hipotesis promosi} sekolah terhadap perolehan siswa.

Uji $t$ untuk $b_{2 \cdot,}$ Uji $t$ untuk $\mathrm{b}_{2}$ dilakukan untuk menguji hipotesis ketiga yaitu :

$\mathrm{HO}: \mathrm{b}_{2}=0$ tidak terdapat pengaruh Promosi sekolah menengah terhadap Perolehan Jumlah Siswa pada Sekolah menengah (SMA) Maarif Cilegon, $\mathrm{Hi}: b_{2} \neq 0$ terdapat pengaruh Promosi sekolah menengah terhadap Perolehan Jumlah Siswa di Sekolah menengah (SMA) Maarif Cilegon.

Jika $\mathrm{t}$ hitung $>\mathrm{t}$ tabel, maka $\mathrm{H}_{0}$ ditolak dan $\mathrm{H}_{1}$ diterima.

Hasil perhitungan uji t dengan bantuan pengolahan komputer berdasarkan perhitungan SPSS 15.0 diperoleh nilai koefisien $t$ hitung untuk $b_{2}$ sebagai berikut :

$$
\begin{aligned}
t_{\text {hitung }} & =\frac{b_{2}}{\operatorname{Se}\left(b_{2}\right)} \\
t_{\text {hitung }} & =\frac{0,3283}{0,02146}=15,290
\end{aligned}
$$

Dari perhitungan SPSS tersebut, nilai $t$ hitung yang diperoleh adalah sebesar 15,290 sedangkan $t$ tabel dengan derajat bebas 113 pada $\alpha$ $(0,025)$ adalah sebesar 1,9818. Dengan demikian $t$ hitung $(15,290)>t$ tabel $(1,9818)$, sehingga jelas $\mathrm{H}_{0}$ ditolak dan $\mathrm{H}_{1}$ diterima. Hal ini menunjukkan bahwa Promosi sekolah menengah dapat meningkatkan Perolehan Jumlah Siswa di Sekolah menengah (SMA) Maarif Cilegon.

\section{PEMBASHASAN}

\section{Pengaruh Kualitas} Pendidikan terhadap Perolehan Jumlah Siswa pada Sekolah menengah (SMA) Maarif Cilegon.

Analisis variabel Kualitas Pendidikan terhadap Perolehan Jumlah Siswa pada sekolah menengah (SMA) Maarif Cilegon berpengaruh secara positif dan signifikan. Hal ini ditunjukkan dari nilai $t$ hitung untuk $b_{1}$ yang diperoleh adalah sebesar 7,750 sedangkan $t_{\text {tabel }}$ dengan derajat bebas (df) 113 pada alfa (a) 0,025 adalah sebesar 1,9818. Dengan demikian $t_{\text {hitung }}(7,750)>t_{\text {tabel }}$ 
$(1,9818)$. Hal ini menunjukan bahwa dalam Kualitas Pendidikan dapat meningkatkan Perolehan Jumlah Siswa pada sekolah menengah (SMA) Maarif Cilegon.

Tanggung jawab dalam Kualitas Pendidikan terletak sepenuhnya pada pribadi masing-masing guru dan siswa itu sendiri dalam melaksanakan tugas belajar mengajar. Semua pihak lain, seperti kepala sekolah, pemerintah, dan orangtua hanya berperan memberikan bantuan. Jika ada kesempatan seperti keikutsertaan dalam program pelatihan, melanjutkan pendidikan diluar jam kerja atau berusaha supaya dialihtugaskan, apabila secara sukarela dimanfaatkan akan berakibat secara positif, bukan hanya berupa keuntungan bagi pribadi sendiri, akan tetapi juga bagi organisasi. Disamping manfaat profesional, ada pula manfaat psikologis bagi guru yang bersangkutan karena dipandang oleh berbagai pihak lain, seperti atasan dan bagian kepegawaian, sebagai manifestasi keinginan yang bersangkutan untuk bertumbuh dan berkembang.

Oleh karena itu, agar Perolehan Jumlah Siswa pada sekolah menengah (SMA) Maarif Cilegonmeningkat, maka dalam Kualitas Pendidikan harus lebih baik. Dengan demikian, Kualitas Pendidikan sangat penting dalam upaya peningkatan Perolehan Jumlah Siswa pada sekolah menengah (SMA) Maarif Cilegon, di mana peningkatan Perolehan Jumlah Siswa akan sangat berpengaruh terhadap pencapaian target kerja di sekolah menengah (SMA) Maarif Cilegon yang maksimal.

\section{Pengaruh Promosi sekolah} menengah terhadap Perolehan Jumlah Siswa pada sekolah menengah (SMA) Maarif Cilegon.

Analisis variabel Promosi sekolah menengah terhadap Perolehan Jumlah Siswa pada sekolah menengah (SMA) Maarif Cilegon berpengaruh secara positif dan signifikan. Hal ini ditunjukkan dari nilai $t$ hitung untuk $b_{2}$ yang diperoleh adalah sebesar 15,290 sedangkan $t_{\text {tabel }}$ dengan derajat 
bebas (df) 113 pada alfa ( $\alpha$ ) 0,025 adalah sebesar 1,9818. Dengan demikian $t_{\text {hitung }}(15,290)>t_{\text {tabel }}$ (1,9818). Hal ini menunjukkan bahwa Promosi sekolah menengah dapat meningkatkan Perolehan Jumlah Siswa pada sekolah menengah (SMA) Maarif Cilegon.

Promosi sekolah menengah telah dianggap sebagai pencipta kondisi (pengaruh situasi yang bersifat deterministic dan amat berpengaruh yang merupakan prasyarat bagi peningkatan jumlah siswa dalam hal penerimaan siswa baru dan partisipasi dimaksud. Semakin tinggi promosi sekolah menengah yang lakukan dalam melaksanakan rekruitmen siswa maka efektivitas akan tercapai hal tersebut menunjukkan adanya peningkatan perolehan jumlah siswa.

Ditinjau dari dimensi variabel Promosi sekolah menengah yang diamati, dari dimensi "Peluang" dimensi "Peluang kepuasan psikologis" dan dimensi "Peluang belum ada pesaing“ menunjukkan hasil yang belum memuaskan. Hal ini menunjukan promosi sekolah menengah pada sekolah menengah (SMA) Maarif Cilegon masih perlu ditingkatkan. Dilihat dari kesempatan untuk memperoleh Promosi sekolah menengah untuk menaikan jumlah siswa sangat sedikit, belum maksimalnya Promosi sekolah menengah dalam pemberian brosur kepada masyarakat, dan sosialisasi keberadaan sekolah menengah (SMA) Maarif Cilegon yang belum maksimal.

Berdasarkan uraian di atas, maka dapat dilihat bahwa Perolehan Jumlah Siswa pada sekolah menengah (SMA) Maarif Cilegon akan tercapai apabila Promosi sekolah menengah dilakukan dengan gencar di Sekolah Menengah Atas (SMA) Maarif Cilegon ditingkatkan.

\section{Pengaruh Kualitas Pendidikan} dan Promosi sekolah menengah secara bersam-sama terhadap Perolehan Jumlah Siswa Sekolah menengah (SMA) Maarif Cilegon.

Sebagaimana diuraikan pada bagian uji hipotesis, bahwa variabel Kualitas Pendidikan dan Motovasi kerja secara bersamasama berpengaruh positif terhadap Perolehan Jumlah Siswa pada 
Sekolah menengah (SMA) Maarif Cilegon. Hal ini ditunjukkan dari nilai $\mathrm{F}_{\text {hitung }}$ yang diperoleh sebesar 238,446 , sementara harga kritis nilai $F$ tabel dengan derajat bebas pembilang 2 dan penyebut 113 pada a ( 0,05) sebesar 3,673 sehingga terbukti bahwa $F$ hitung ( $238,446)>F_{\text {tabel }}(3,673)$. Dengan demikian bahwa variabel Kualitas Pendidikan dan Promosi sekolah menengah secara bersama-sama dapat meningkatkan Perolehan Jumlah Siswa pada Sekolah Menengah Atas (SMA) Maarif Cilegon.

Hasil penelitian ini juga menggambarkan bahwa sebanyak $80,8 \%$ keragaman variabel Perolehan Jumlah Siswa pada Sekolah menengah (SMA) Maarif Cilegon disebabkan oleh perbedaan keragaman variabel Kualitas Pendidikan dan Promosi sekolah menengah, sisanya sebanyak $19,2 \%$ disebabkan oleh faktor lain yang tidak diteliti. Dengan demikian pengaruh kedua faktor tersebut terhadap peningkatan Perolehan Jumlah Siswa pada Sekolah menengah (SMA) Maarif Cilegon sangat berarti.
Ditinjau dari dimensi variabel Perolehan Jumlah Siswa yang diamati, diperoleh Pertama, dari dimensi "Kualitas manajemen" menunjukkan bahwa kualitas manajemen pada Sekolah Menengah Atas (SMA) Maarif Cilegon belum ideal. Artinya kualitas manajemen masih perlu ditingkatkan. Hal ini dapat dilihat dari kurangnya pemahaman dalam melaksanakan tugas yang telah direncanakan sebelumnya dan evaluasi kerja yang belum maksimal. Kedua, dari dimensi "kualitas Pendidikan" dan dimensi "kepegawaian yang efektif" masih menunjukkan hasil yang belum memuaskan. Hal ini disebabkan kemampuan manajerial dan human skill pemimpin yang masih belum maksimal

Berdasarkan uraian tersebut maka Perolehan Jumlah Siswa pada Sekolah menengah (SMA) Maarif Cilegon perlu ditingkatkan. Peningkatan Jumlah Siswa ini dapat dilakukan melalui peningkatan dalam Kualitas Pendidikan serta peningkatan Promosi sekolah. 
SIMPULAN.

Berdasarkan hasil penelitian dan pembahasan mengenai pengaruh kualitas pendidikan dan promosi sekolah terhadap peningkatan perolehan jumlah siswa pada Sekolah Menengah Atas (SMA) Maarif Cilegon, maka dapat disimpulkan hal-hal sebagai berikut:

1. Faktor kualitas pendidikan dan kurangnya promosi pada SMA Maarif Cilegon secara bersamasama mempunyai pengaruh yang positif terhadap peningkatan jumlah perolehan siswa SMA Maarif Cilegon, dengan kata lain semakin baik kualitas proses belajar mengajar dan semakin gencar dalam promosi ke masyarakat luas, maka akan semakin meningkat tingkat perolehan jumlah siswa pada SMA Maarif Cilegon.

2. Kualitas Pendidikan mempunyai pengaruh yang positif terhadap peningkatan Perolehan Jumlah Siswa pada Sekolah Menengah Atas Maarif Cilegon, dengan kata lain semakin baik dalam berpromosi, maka semakin meningkatkan jumlah perolehan siswa pada Sekolah Menengah Atas (SMA) Maarif Cilegon.

3. Kurangnya Promosi Sekolah mempunyai pengaruh yang positif terhadap peningkatan jumlah perolehan siswa, dengan kata lain semakin baik tingkat promosinya kepada masyarakat luas dilakukan, maka akan semakin meningkatkan jumlah perolehan siswa pada Sekolah Menengah Atas (SMA) Maarif Cilegon.

4. Diperoleh keragaman perolehan jumlah siswa sekolah menengah (SMA) Maarif

Cilegon disebabkan oleh keragaman kualitas pendidikan dalam proses belajar

mengajar dan Promosi sekolah menengah yang dilakukan kepada masyarakat.

\section{Saran-saran}

Berdasarkan pada hal-hal di atas, saran-saran yang dapat dikemukakan adalah sebagai berikut:

1. Manajemen sekolah menengah (SMA) Maarif Cilegon harus benar-benar memperhatikan dalam peningkatan kualitas proses belajar mengajar 
dengan melihat ketiga aspek tersebut, sehingga perolehan jumlah siswa merupakan produk yang handal dan berkualitas baik yang pada gilirannya akan memberikan kepuasan pada pelanggan (customer statification)

2. Agar meningkatkan pelayanan dalam melayanai para konsumen dalam hal ini siswa yang diakibatkan oleh kualitas proses belajar mengajar dan memberikan pelayan secara profesional, selain itu pada proses sosialisasi harus benar-benar memperhatikan kualitas guru dan kualitas meteri yang akan di ajarkan untuk siswa tersebut, sehingga dapat memenuhi kualifikasi dan spesifikasi yang diinginkan oleh konsumen yang pada akhirnya dapat meningkatkan jumlah perolehan siswa.

3. Diusulkan kepada pihak manajemen Sekolah Menengah Atas (SMA) Maarif Cilegon, agar melakukan evaluasi setiap tiga (3) bulan guna untuk mengadakan perbaikan dengan langkah-langkah yang diperlukan. Sehingga apabila terjadi sesuatu yang tidak sesuai dengan ketentuan akan lebih cepat terdeteksi dan cepat diadakan suatu langkahlangkah perbaikan.

\section{DAFTAR PUSTAKA}

Badan Akreditasi Sekolah. (2002). Kriteria penilaian sekolah, Jakarta, BASN.

Daft, R. L. (2010). Era Baru Manajemen, New Era of Management, Jakarta, Salemba Empat, 2010

Danim, S. (2010). Inovasi Pendidikan dalam Upaya Peningkatan Profesionalisme Tenaga Kependidikan, Bandung, Pustaka Setia.

Drucker, P. (1999). Management Chalanges for $21^{\text {th }}$ century. New York Harper Collins Publishers.

Handoko, H. T. (2000). Dasar-dasar Manajemen Produksi dan Operasi. Yogyakarta: edisi I BPFE.

Heizer, Jay and Render, B. (1995). Production and Operation Management Strategic and Tactical Decisions. New Jersey: Prentice Hall.

Kotler, P. (1998). Managemen Pemasaran, Marketing Management 9e, Analisis, Perencanaan, Implementasi dan 
Kontrol, New Jersey: Simon and Schuster.

Moeheriono. (2009). Pengukuran Kinerja Berbasis Kompetensi. Jakarta: Ghalia Indonesia.

Ndraha, T. (2003). Budaya Organisasi. Jakarta: Rineka Cipta.

Notoatmojo, $\mathrm{S}$. (2003). Pengembangan Sumber Daya Manusia. Jakarta: Rineka Cipta.

Purwanto, I. (2006). Manajemen Strategi. Bandung: Yrama Widya.

Rangkuti, F. (2007). Riset Pemasaran. Jakarta: Gramedia.

Russel, R dan Taylor III. 1995). Production and Operations Manajemen Focusing on Quality dan Competitiveness. New Jersey: Prentice Hall.

Sallis, Edward. (2008).Total Quality Management in Education, Manajemen Mutu Pendidikan. Yogyakarta: IRCiSoD, 2008

Sconberger, JR dan Knod, ME. (1997). Operation Managemet Customers-Focused Prinsiples. Chicago: Sixth Edition IRWIN.
Siagian, Sondang P. (2003). Filsafat Administrasi. Jakarta: Bina Aksara.

Soekarsono, R. (2003). Kualitas Kerja Auditor. Jakarta: Disertasi Universitas Negeri Jakarta.

Sugiyono. (2006). Metode Penelitian Administrasi. Bandung: Alfabeta. (2005). Metode Penelitian Bisnis, Bandung, Alfabeta, 2005

Stamatis, D H. (1996). Total Quality Service, St. Lucia Press USA, 1996

Ulrich, T.K. dan Steven, D.E. (2001). Perancangan dan Pengembangnan Produk. Jakarta: Sahabat Teknik.

Universitas Pendidikan Indonesia, Tim Dosen Administrasi Pendidikan. (2010). Manajemen Pendidikan. Bandung: Alfabeta.

Usman, Husaini. (2009). Manajemen, Teori, praktek dan Riset Pendidikan. Jakarta: Bumi Aksara. 